\title{
Isolation and Characterization of Multi-Drug Resistant Bacteria from Hospital Wastewater Sites around the City of Aizawl, Mizoram
}

\author{
Lalremruata Hauhnar*\#, Lallianmawii Pachuau*, H. Lalhruaitluanga\# \\ Department of Biotechnology, Mizoram University, Aizawl, India \\ Email: "teteahauhnar@gmail.com, "mahruaia123@gmail.com
}

How to cite this paper: Hauhnar, L., Pachuau, L. and Lalhruaitluanga, H. (2018) Isolation and Characterization of Multi-Drug Resistant Bacteria from Hospital Wastewater Sites around the City of Aizawl, Mizoram. Advances in Bioscience and Biotechnology, 9, 311-321.

https://doi.org/10.4236/abb.2018.97020

Received: May 11, 2018

Accepted: July 9, 2018

Published: July 12, 2018

Copyright (c) 2018 by authors and Scientific Research Publishing Inc. This work is licensed under the Creative Commons Attribution International License (CC BY 4.0). http://creativecommons.org/licenses/by/4.0/

\section{Open Access}

\begin{abstract}
A microbial study was conducted from wastewater soils of hospitals in Aizawl, Mizoram, India which were in existence for a longtime. The isolated bacteria from the wastewater soils were found to be mainly of Morganella morganii and Bacillus cereus and these isolated bacteria were found to be very resistant to a wide range of antibiotics and heavy metals. Antibiotics that were used for treating infections caused by these bacteria like chloramphenicol and ciprofloxacin were also found to be insensitive. The degree of resistance was also very high when compared to earlier reports of antibiotic resistance observed in the corresponding bacteria. Our results suggested that the high degree of resistance is probably conferred by the continued exposure to antibiotics from hospital waste leading to a selected population of highly antibiotics-resistant bacteria.
\end{abstract}

\section{Keywords}

Isolated Bacteria, Multidrug Resistance, Hospital Wastewater

\section{Introduction}

The high usage of antibiotics in hospitals and other health establishments to treat diseases leading to antibiotic resistance is a common problem, but the antibiotics and resistance to antibiotics as environmental problems and pollutants have largely been overlooked. Uncontrolled and excessive use of antibiotics in health establishments usually leads to an increase in antibiotic resistance and causes the spread of resistance genes in the surrounding environment through hospital waste water [1]. As a result of continuous contamination with antibiotic residues, development and evolution of antibiotic resistant bacteria is a major ${ }^{\star}$ Equal Authors. 
concern [2] [3].

Hospital wastewater is a highly selective pollutant that contributes to the high rates of resistant bacteria that are being discharged in the natural environment [4]. The antibiotics pollutants contained in hospital wastewater exert a selection in favor of resistant bacteria by killing or inhibiting the growth of susceptible bacteria. This leads to the mass increase resistant bacteria as the competing flora had been wiped out by the pollutants [5]. The increase in resistant bacteria can also be contributed by the transfer of resistant genes between bacterial species through transduction or conjugation [6]. Integrons which are DNA elements that mediate integration of resistant genes, may also be involved [7]. All these processes can lead to the development of a super bug/multidrug resistant bacterium which is resistant to a variety of antibiotics. There is a chance that the resistance genes might get transferred from environmental bacteria to pathogenic bacteria that cause diseases in human and this becomes a public health problem [5] [8].

It had also been reported that hospital wastewater also contains a variety of toxic compounds and persistent molecules such as heavy metals [9] [10]. Among the heavy metals present in hospital wastewater, cadmium and lead are very toxic and very persistent in the environment as they cannot be biodegraded. The presence of heavy metals in hospital wastewater can also leads to contamination of the receiving water and hazardous impact on aquatic life. Lead reacts with sulfhydryl groups of proteins and inhibits their function while cadmium binds to respiratory enzymes causing oxidative stress and DNA damage [11] [12]. The microbial fauna in hospital wastewater has acquired a variety of mechanisms for resistance to drugs and toxic elements [13] [14]. Most microorganisms developed resistance to toxic compounds and antibiotics with the help of a specific gene, and they were mostly found on plasmids or on chromosomes [15] [16]. There had been several reports of resistance to both heavy metals and antibiotics among resistant bacteria [13] [17].

The purpose of this study is isolation and characterization of bacteria from hospital wastewaters to check whether they are resistant to antibiotics or heavy metals or both and to create awareness for proper waste disposal from hospital effluents for reducing public health risk.

\section{Materials and Methods}

\subsection{Chemicals}

All chemicals and reagents were purchased from Merck (India), HiMedia (India) and SRL (India) unless otherwise stated.

\subsection{Enrichment of Soil Bacteria}

Soil samples were collected from sewage disposal site of Aizawl Civil Hospital and of Falkawn Referral Hospital, Aizawl and were named as HC and HR respectively. $1 \mathrm{~g}$ of the soil sample was enriched in minimal media (Tris base 14.5 
g; $\mathrm{NaCl} 4.68 \mathrm{~g} ; \mathrm{KCl} 1.5 \mathrm{~g}, \mathrm{NH}_{4} \mathrm{Cl} 1.0$ g, glycerol $5 \mathrm{ml}, \mathrm{K}_{2} \mathrm{SO}_{4} 0.0043 \mathrm{~g}, \mathrm{CaCl}_{2} 0.003$ $\mathrm{g}$ in total volume of $1 \mathrm{~L}$ ) for 24 hours at $37^{\circ} \mathrm{C}$.

\subsection{Growth Conditions}

A primary culture of bacteria was grown in LB media. The cells were allowed to grow at $37^{\circ} \mathrm{C}$ for 16 hours. The primary cultures were grown again in a fresh LB media for 4 hours. Cells were resuspended in saline $(0.9 \% \mathrm{NaCl})$ and the O.D. was adjusted to 0.1 at $600 \mathrm{~nm}$ and five-fold serial dilutions were made. $5 \mu \mathrm{l}$ of cell suspensions from each dilution were spotted on to the LB media plates in the absence and presence of the test compounds. The plates were incubated at $37^{\circ} \mathrm{C}$ for 12 hours.

\subsection{Gram Staining}

Overnight cultures of each strain were fixed on a slide by gently heating. The slides were first stained with crystal violet for 1 minute and then washed with water. The slides were flooded with iodine solution for 1 minute and then washed again with water. The slides were flooded with a decolorizer for a few seconds and washed again with water followed by staining with safranin for 30 seconds and the excess safranin was washed off with water. The slides were dried, 30\% glycerol were added, covered with a cover slip and viewed under a microscope.

\subsection{Genomic DNA Isolation of Bacterial Strain}

$10 \mathrm{ml}$ of overnight culture was harvested by centrifugation for 10 minutes at $5000 \mathrm{rpm}$ and the pellet was resuspended in $875 \mu \mathrm{l}$ of TE buffer. $100 \mu \mathrm{l}$ of $10 \%$ SDS and $5 \mu \mathrm{l}$ of Proteinase $\mathrm{K}(10 \mathrm{mg} / \mathrm{ml}$ stock) were again added and the mixture was incubated at $37^{\circ} \mathrm{C}$ for 1 hour. Equal volume of phenol-chloroform mixture was added to the mixture, mixed by inverting and incubated at room temperature for 5 minutes. The mixture was then centrifuged at 10,000 rpm for 10 minutes at $4^{\circ} \mathrm{C}$ and the supernatant was collected in a fresh tube. $100 \mu \mathrm{l}$ of 5 $\mathrm{M}$ sodium acetate was added and mixed gently. Then $1 \mathrm{ml}$ of isopropanol was added to the mixture and incubation was done at room temperature for $30 \mathrm{mi}$ nutes. The mixture was centrifuged at $12,000 \mathrm{rpm}$ for 10 minutes and the pellet was washed with $70 \%$ ethanol 3 times. The pellet was dried at room temperature and resuspended in $50 \mu \mathrm{l}$ of TE buffer.

\subsection{S rRNA Amplification and Sequencing}

The 16S rRNA gene of each strain was amplified using the primers 5'AGAGTTTGATCCTGGCTCAG-3' (FP) and

5'-TACGGTTACCTTGTTACGACT T-3' (RP). The PCR conditions used were initial denaturation of 5 minutes at $94^{\circ} \mathrm{C}$ followed by 30 cycles of denaturation of 60 seconds at $94^{\circ} \mathrm{C}$, annealing of 45 seconds at $52^{\circ} \mathrm{C}$ and extension of 90 seconds at $72^{\circ} \mathrm{C}$. The final extension used was for 10 minutes at $72^{\circ} \mathrm{C}$ followed by holding at $4^{\circ} \mathrm{C}$. 
Sequencing of the $16 \mathrm{~S}$ rRNA of the isolated resistant strains was done with BigDye Terminator Cycle Sequencing Kit (Applied Biosystems) little modifications. The sequences obtained were matched with previously published data in NCBI databases using BLAST. Only the first 755 nucleotides were sequenced using the forward primer and used for species identification.

\subsection{Antibiotic Resistance Studies}

To study the antibiotic resistance profile of the bacteria, LB agar plates were prepared with appropriate concentration of antibiotics. A primary culture of each soil bacteria was grown overnight, then a secondary culture was grown again using the primary culture. The O.D of secondary bacterial culture was adjusted to 0.1 at $600 \mathrm{~nm}$. Five-time serial dilution was made and plated on the antibiotic containing LB agar plates. The bacterial strain of DH5 $\alpha$ was used as a control.

\subsection{Heavy Metal Resistance Studies}

As above, LB agar plates were prepared with appropriate concentration of antibiotics to study the heavy metal resistance profile of the bacteria. A primary culture of each soil bacteria was grown overnight, then a secondary culture was grown again using the primary culture. The secondary bacterial culture was 5 time serially diluted using saline after the OD was adjusted to 0.1 at $600 \mathrm{~nm}$ and $5 \mu \mathrm{l}$ of the serially diluted cultures was spotted onto LB plates containing the different metal concentrations. The bacterial strain of DH5 $\alpha$ was used as a control.

\section{Results}

\subsection{Isolation of Soil Bacteria}

Soil samples were collected from hospital wastewater sites of Aizawl, Mizoram. The soil bacteria collected from Aizawl Civil Hospital and Falkawn Referral Hospital were named HC and HR respectively. The soil bacteria were enriched in minimal media for 24 hours at $37^{\circ} \mathrm{C}$ and grown on a fresh $\mathrm{LB}$ media overnight again at $37^{\circ} \mathrm{C}$ to be used as a primary culture which contains. From these primary cultures, a population of bacterial species were isolated from each soil and further used for analysis.

\subsection{Microbiological Analysis}

Gram staining was done for both the isolated bacterial strain and found that $\mathrm{HC}$ strain was found to be gram-negative while HR was Gram positive as shown in Figure 1. Both the isolated bacteria were found to be rod shaped, but HC was found to be smaller than HR in size.

\subsection{Identification of Bacteria Using $16 \mathrm{~S}$ rRNA}

$16 \mathrm{~S}$ rRNA gene was amplified in both strains to identify the species. It was found 

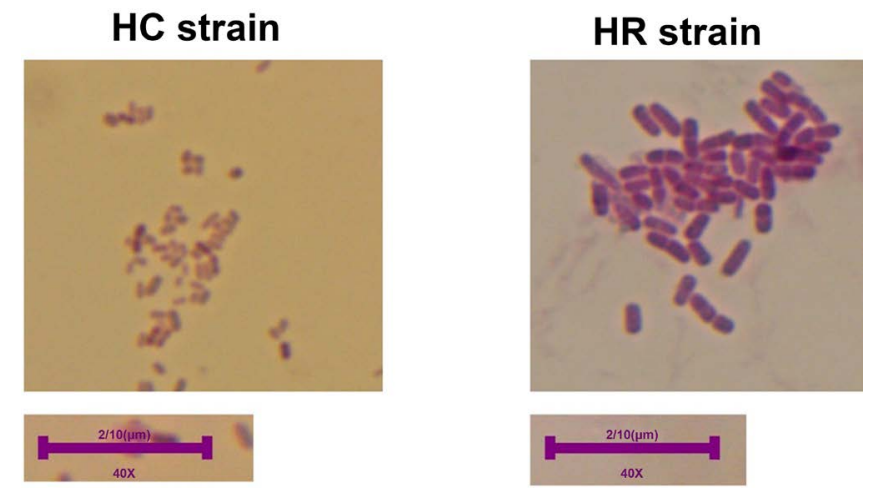

Figure 1. Gram staining of isolated bacteria from hospitals.

that HC strain was of Morganella morganii while the HR stain was found to be of Bacillus cereus. The partial sequences were submitted to GenBank and their accession no was MH285257 for HC and MH327509 for HR. This experiment also confirmed the above microbiological analysis as $M$. morganii were rod shaped gram-negative bacteria with a size of $1-1.7 \mu \mathrm{m}$ in length while $B$. cereus were rod shaped gram-positive bacteria with a length of $3-4 \mu \mathrm{m}$ [17] [18] [19]. A phylogenetic tree was constructed using $16 \mathrm{~S}$ rRNA sequences for both the strain as shown in Figure 2 and Figure 3.

\subsection{Antibiotic Resistance Profile of the Isolated Bacteria}

As mentioned before, hospital wastewaters contains lots of toxic substances that can cause selection of toxic bacteria and isolation of slightly resistant bacteria is very common [5]. Therefore, we examined the antibiotic resistance profile of these isolated bacteria by spot assays on LB media plates containing appropriate antibiotic concentrations. The strains HC and HR possessed a very degree of resistance to ampicillin, and both grew nicely even at $200 \mu \mathrm{g} / \mathrm{ml}$ of ampicillin while $100 \mu \mathrm{g} / \mathrm{ml}$ is the recommended concentration for laboratory bacterial selection as shown in Figure 4. The control DH5 $a$ could not grow at all as it lacks plasmid conferring ampicillin resistance.

The bacterial strains were also checked for resistance to kanamycin, another common antibiotic. The strain HC is found to be most resistant to kanamycin and still grows very well even at a high concentration of $100 \mu \mathrm{g} / \mathrm{ml}$ as shown below in Figure 4. While HR also showed a very high resistance to kanamycin even at $100 \mu \mathrm{g} / \mathrm{ml}$ but the degree of resistance was less when compared to the other isolated strain HC.

Chloramphenicol is a common antibiotic used for the treatment of bacterial infections in humans. It is a semisynthetic, broad spectrum antibiotic and derived from Streptomyces venezuelae. It blocks protein synthesis in bacteria by binding to the 50S ribosome and reduces peptidyl transferase activity [20]. The two strains were treated with chloramphenicol and found that they were very resistant compared to the control DH5 $\alpha$, especially HC strain which survives even at a high concentration of $50 \mu \mathrm{g} / \mathrm{ml}$ as shown in Figure 5. 


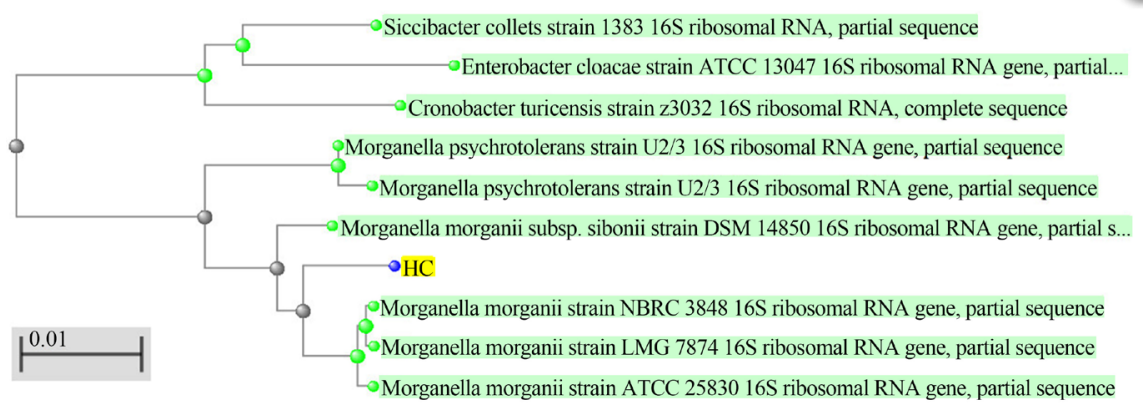

Figure 2. Phylogenetic tree for HC strain constructed from 16S rRNA gene sequences.

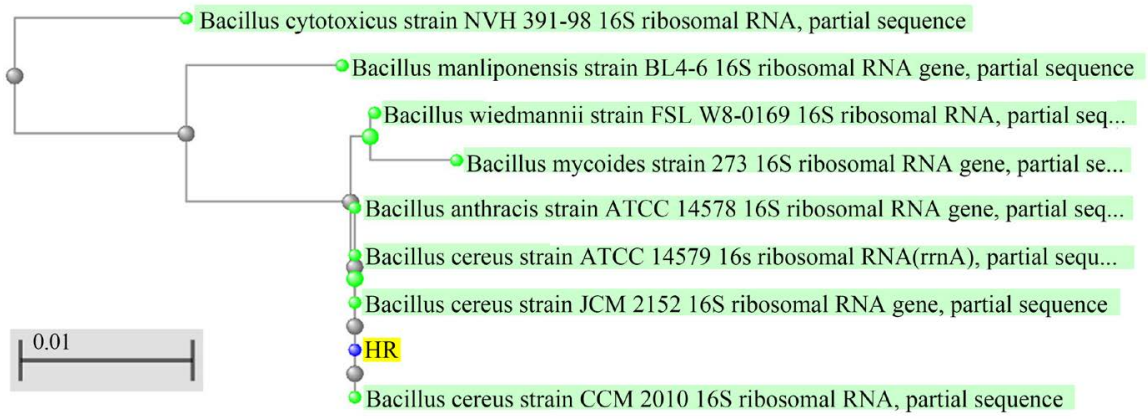

Figure 3. Phylogenetic tree for HR strain constructed from 16S rRNA gene sequences.

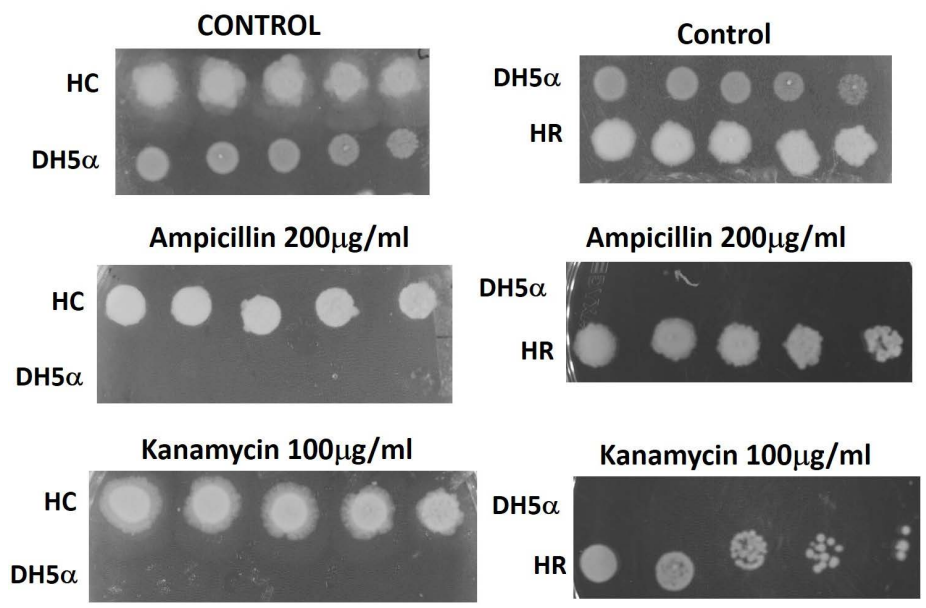

Figure 4. Treatment of isolated bacteria with ampicillin and kanamycin. Secondary cultures grown for $4 \mathrm{hrs}$ were suspended in normal saline and the OD was adjusted to 0.1 at $600 \mathrm{~nm} .5 \mu \mathrm{l}$ of the serially diluted cultures was spotted onto LB plates in the absence and presence of ampicillin and kanamycin.

The isolated bacterial strains were also treated with ciprofloxacin, a fluoroquinolone antibiotic that inhibits bacterial DNA gyrase and used for treatment of various bacterial infections [21]. It was found that the two strains were very resistant to the treatment of ciprofloxacin compared to control DH5 $\alpha$ as shown in Figure 5. The strain from Aizawl Civil Hospital, HC showed a very high resistance to ciprofloxacin and a very high concentration of $50 \mu \mathrm{g} / \mathrm{ml}$ could not eliminate the HC strains. 
CONTROL

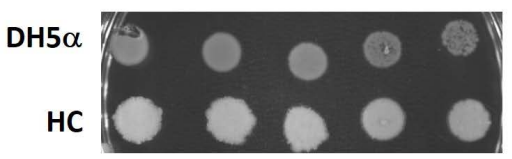

Chloramphenicol $50 \mu \mathrm{g} / \mathrm{ml}$

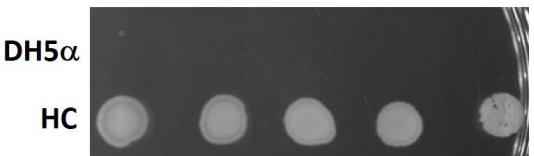

Ciprofloxacin $50 \mu \mathrm{g} / \mathrm{ml}$

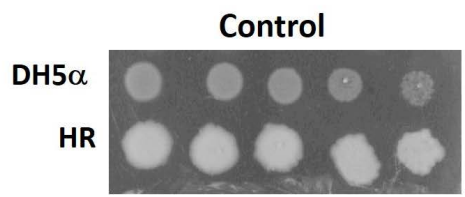

Chloramphenicol $10 \mu \mathrm{g} / \mathrm{ml}$

DH5 $\alpha$

HR

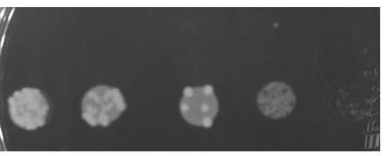

Ciprofloxacin $10 \mu \mathrm{g} / \mathrm{ml}$

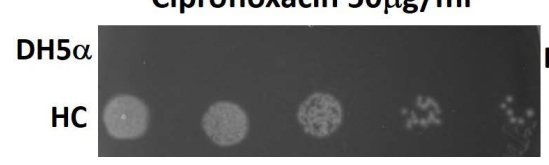

DH5 $\alpha$

HR

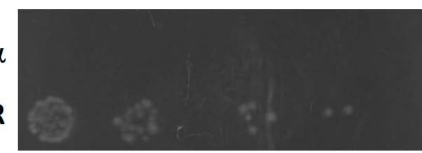

Figure 5. Treatment of isolated bacteria with chloramphenicol and ciprofloxacin. Secondary cultures grown for $4 \mathrm{hrs}$ were suspended in normal saline and the OD was adjusted to 0.1 at $600 \mathrm{~nm}$. $5 \mu \mathrm{l}$ of the serially diluted cultures was spotted onto LB plates in the absence and presence of chloramphenicol and ciprofloxacin.

\subsection{Heavy Metal Resistance Profile of the Bacteria}

Heavy metal contamination is a common occurrence in hospital sewage disposal site. There were lots of reports showing the resistance of microbial fauna to heavy metals found in the hospital wastewater [13] [14]. Therefore, heavy metal resistance profile of the isolated species was next studied by spot assays on LB media plates containing appropriate concentrations of heavy metals. We found that soil bacteria isolated from Aizawl Civil Hospital (HC) and Falkawn Referral Hospital ( $\mathrm{HR}$ ) were found to be very resistant to lead $(\mathrm{Pb})$ and cadmium $(\mathrm{Cd})$ compared to DH $5 \alpha$. Both the strain grew very well at $5 \mathrm{mM}$ lead nitrate while the control DH5 $\alpha$ could not grow well at the same concentration of lead nitrate as shown in Figure 6. At $1 \mathrm{mM}$ of cadmium nitrate, both $\mathrm{HC}$ and HR strains grew while DH5 $\alpha$ does not grow at all shown below in Figure 6.

\section{Discussion}

Hospital wastewater contains lots of toxic substances that can pollute the surrounding environment including rivers. These toxic substances play an important role in the selection of bacterial species found in the environment as well as the ones that occurs in the waste water [1] [4] [10]. Because of these selection pressures, two different resistant bacterial species were identified, one each from the two hospitals. The bacterial species were Morganella morganii from Aizawl Civil Hospital and Bacillus cereus from Falkawn Referral Hospital.

Morganella morganii is a non-lactose fermenting bacterium, motile and gram-negative bacteria. They have a wide range of distribution found commonly in the environment as well as the intestinal tracts of humans and animals [18] [19]. The wide distribution of M. morganii does not necessarily account for 

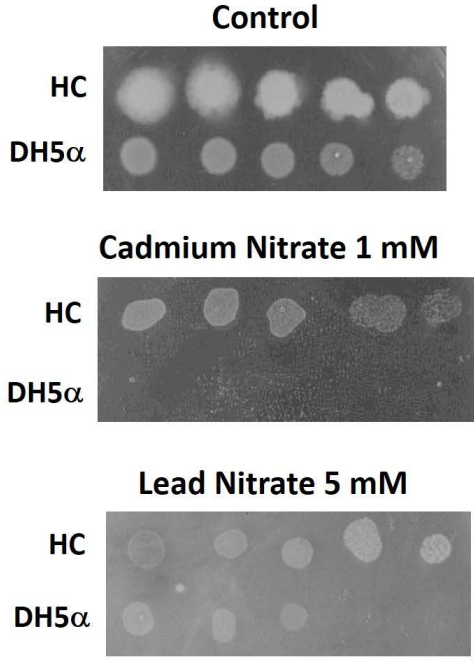
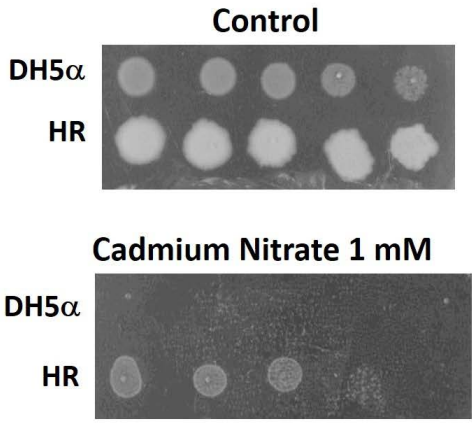

Lead Nitrate $7 \mathrm{mM}$

$\mathrm{DH} 5 \alpha$

HR

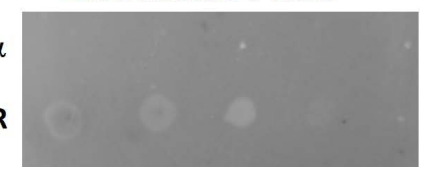

Figure 6. Treatment of isolated bacteria with heavy metals. Secondary cultures grown for $4 \mathrm{hrs}$ were suspended in normal saline and the OD was adjusted to 0.1 at $600 \mathrm{~nm} .5 \mu \mathrm{l}$ of the serially diluted cultures was spotted onto LB plates in the absence and the absence and presence of cadmium nitrate and lead nitrate.

causing infections and diseases in humans, and in fact it considered to be an uncommon cause of community-acquired infection and encountered mostly in post-operative and other nosocomial infections [18] [19] [22]. M. morganii were known to be naturally resistant to beta-lactam family of antibiotics like ampicillin, penicillin, etc [23] [24]. But they were found to be sensitive to a wide range of antibiotics like fluoroquinolones (ciprofloxacin), aminoglycosides, chloramphenicol, cephalosporins, aztreonam, etc. [25] [26]. Here in our studies, we found that the isolated strain of M. morganii from Aizawl Civil Hospital were very resistant to aminoglycosides like kanamycin $(100 \mu \mathrm{g} / \mathrm{ml})$. The level of resistance that had been reported were very high compared to previous studies that had shown a resistance to kanamycin at a lower level compared to the one that was found here [25]. Ciprofloxacin and chloramphenicol are two broad spectrum antibiotics that are used for treating different types of bacterial infection. These two antibiotics are found to be very effective in treating against M. morganii infections as they are naturally sensitive. Earlier report had shown that $M$. morganii was found to be very sensitive to the treatment of chloramphenicol [26]. But here in our studies, it was found that a high concentration of $50 \mu \mathrm{g} / \mathrm{ml}$ was still not enough to significantly affect the growth of isolated strain. It was also earlier reported that $0.25 \mu \mathrm{g} / \mathrm{ml}$ of ciprofloxacin was enough to inhibit the growth of M. morganii [26] [27], but the isolated bacterial strain from Aizawl Civil Hospital was found to be very resistant to this concentration and even a high concentration of $50 \mu \mathrm{g} / \mathrm{ml}$ was still not enough for the treatment of the isolated strain.

Bacillus cereus is a gram-positive, spore forming, rod shaped bacterium that is found in all almost all the environment. Its wide distribution includes soil, fresh water, hospital environment and found even in the gastrointestinal flora of hu- 
mans [17] [28] [29]. B. cereus produces two types of toxins, namely thermostable emetic enterotoxin and thermosensitive diarrhoeagenic enterotoxin, that are both known to be involved in food poisoning. It is found in a variety of foods like meat, milk, vegetables, fruits, etc. [28] [30]. B. cereus was known to have natural resistance to beta-lactam antibiotics, but it was also previously shown that $24 \mu \mathrm{g} / \mathrm{ml}$ of ampicillin was enough to kill $90 \%$ of the bacterial population [31]. In our studies the resistant strain that we isolated from State Referral Hospital, Falkawn was found to be extremely resistant to ampicillin, and high concentration of $200 \mu \mathrm{g} / \mathrm{ml}$ was found to be ineffective for the treatment of the isolated bacteria. This shows that the resistant B. cereus isolated from Falkawn Referral Hospital shows that it acquired additional resistance mechanism other than the natural resistant mechanism shown in previous studies. Aminoglycoside groups of antibiotics were known to be effective against $B$. cereus and used for the treatment of $B$. cereus infections [31]. But the isolated $B$. cereus strain was found to be very resistant to the treatment of kanamycin and still grows very well even at $100 \mu \mathrm{g} / \mathrm{ml}$. It was earlier reported that $4 \mu \mathrm{g} / \mathrm{ml}$ of chloramphenicol was enough for treatment of $B$. cereus but we found that $10 \mu \mathrm{g} / \mathrm{ml}$ was not enough to inhibit the growth of the isolated strain. It was also found that the isolated strain was very resistant to treatment of $10 \mu \mathrm{g} / \mathrm{ml}$ of ciprofloxacin even though $0.25 \mu \mathrm{g} / \mathrm{ml}$ was reported to efficiently kill $90 \%$ of B. cereus [32].

Both the isolated strains of resistant bacteria were also found to be very resistant to heavy metals like cadmium and lead. The resistance to heavy metals if of somewhat expected as many antibiotic resistant species of isolated soil bacteria were found to be resistant to heavy metals [13] [14] [17].

\section{Conclusion}

The work done had shown that hospital wastewater containing lots of toxic substances including antibiotics was one of the selection forces operating that result in the selection of bacterial population in the surrounding environment of hospitals. The isolated bacterial population as shown was very resistant to the treatment of antibiotics so much so that even high concentrations of antibiotics were not enough to kill the resistant bacterial population. Much of resistance could cause problems in the medical treatment of diseases caused by the isolated bacteria. The ability of the resistant bacteria to transfer its resistant genes to other pathogenic bacteria that can cause even death is a serious problem. The occurrence of multidrug resistant bacteria in the selected sites is a grave concern and should not be overlooked. With the chances of developing super bug that is highly resistant to a wide variety of antibiotics, proper waste water treatment plant should be established and improved. Sanitary measure should be practiced for the safety and wellbeing of patients and hospital workers as well as people who are susceptible to infection.

\section{References}

[1] Iversen, A., Kuhn, I., Franlin, A. and Molby, R. (2002) High Prevalence of Vanco- 
mycin Resistant Enterococci in Swedish Wastewater. Applied Environmental Microbiology, 68, 2838-2842. https://doi.org/10.1128/AEM.68.6.2838-2842.2002

[2] Wise, R., Hart, T., Cars, O., Streulens, M., Helmuth, R., Huovinen, P. and Sprenger, M. (1998) Antimicrobial Resistance Is a Major Threat to Public Health. British Medical Journal, 317, 609-610. https://doi.org/10.1136/bmj.317.7159.609

[3] Mazel, D. and Davies, J. (1999) Antibiotic Resistance in Microbes. Cellular and Molecular Life Sciences, 56, 746-752. https://doi.org/10.1007/s000180050021

[4] Sharpe, M. (2003) High on Pollution: Drugs as Environmental Contaminants. Journal of Environmental Monitoring, 5, 43-46.

[5] Kruse, H. (1999) Indirect Transfer of Antibiotic Resistance Genes to Man. Acta Veterinaria Scandinavica, 92, 59-65.

[6] Berger-Bachi, B. (2002) Resistance Mechanisms of Gram-Positive Bacteria. International Journal of Medical Microbiology, 292, 27-35. https://doi.org/10.1078/1438-4221-00185

[7] Moura, A., Pereira, C., Henriques, I. and Correia, A. (2011) Novel Gene Cassettes and Integrons in Antibiotic-Resistant Bacteria from Urban Wastewaters. Research in Microbiology. (Early On-Line)

[8] Wegener, H., Aarestrup, F., Gerner-Smidt, P. and Bager, F. (1999) Transfer of Resistant Bacteria from Animals to Man. Acta Veterinaria Scandinavica, 92, 51-58.

[9] Verlicchi, P., Galletti, A., Petrovic, M. and Barcelo, D. (2010) Hospital Effluents as a Source of Emerging Pollutants: An Overview of Micropollutants and Sustainable Treatment Options. Journal of Hydrology, 389, 416-428. https://doi.org/10.1016/j.jhydrol.2010.06.005

[10] Kummerer, K. (2010) Pharmaceuticals in the Environment: Sources, Fate, Effects and Risks. Environmental Science and Pollution Research, 17, 519-521. https://doi.org/10.1146/annurev-environ-052809-161223

[11] Ahemad, A. and Mulugeta Kibret, M. (2013) Recent Trends in Microbial Biosorption of Heavy Metals: A Review. Biochemistry and Molecular Biology, 1, 19-26. https://doi.org/10.12966/bmb.06.02.2013

[12] Bruins, M.R., Kapil, S. and Oehme, F.W. (2000) Microbial Resistance to Metals in the Environment. Ecotoxicology and Environmental Safety, 45, 198-207. https://doi.org/10.1006/eesa.1999.1860

[13] Nath, S., Deb, B. and Sharma, I. (2012) Isolation and Characterization of Cadmium and Lead Resistant Bacteria. Global Advanced Research Journal of Microbiology, 1 , 194-198.

[14] Yamina, B., Tahar, B., Lila, M., Hocine, H. and Laure, F.M. (2014) Study on Cadmium-Resistant Bacteria Isolated from Hospital Wastewaters. Advances in Biosciences and Biotechnology, 5, 718-726. https://doi.org/10.4236/abb.2014.58085

[15] Stokes, H.W. and Gillings, M.R. (2011) Geneflow, Mobile Genetic Elements and the Recruitment of Antibiotic Resistance Genes into Gram-Negative Pathogens. FEMS Microbiology Reviews, 35, 790-819. https://doi.org/10.1111/j.1574-6976.2011.00273.x

[16] Hookoom, M. and Puchooa, D. (2013) Isolation and Identification of Heavy Metals Tolerant Bacteria from Industrial and Agricultural Areas in Mauritius. Current Research in Microbiology and Biotechnology, 1, 119-123.

[17] Vilain, S., Luo, Y., Hildreth, M. and Brozel, V. (2006) Analysis of the Life Cycle of the Soil Saprophyte Bacillus cereus in Liquid Soil Extract and in Soil. Applied and Environmental Microbiology, 72, 4970-4977. 
https://doi.org/10.1128/AEM.03076-05

[18] Liu, H., Zhu, J., Hu, Q. and Rao, X. (2016) Morganella morganii, a Non-Negligent Opportunistic Pathogen. International Journal of Infectious Diseases, 50, 10-17. https://doi.org/10.1016/j.ijid.2016.07.006

[19] Falagas, M.E., Kavvadia, P.K., Mantadakis, E., Kofteridis, D.P., Bliziotis, I.A., Saloustros, E., Maraki, S. and Samonis, G. (2006) Morganella morganii Infections in a General Tertiary Hospital. Infection, 34, 315-321.

https://doi.org/10.1007/s15010-006-6682-3

[20] https://pubchem.ncbi.nlm.nih.gov/compound/chloramphenicol\#section=Top

[21] https://pubchem.ncbi.nlm.nih.gov/compound/ciprofloxacin\#section=Top

[22] Farmer, J.J. (1995) Enterobacteriaceae: Introduction and Identification. In: Murray, P.R., Baron, E.J., Pfaller, M.A., Tenover, F.C. and Yolken, R.H., Eds., Manual of Clinical Microbiology, 6th Edition, American Society for Microbiology, Washington DC, 438-449.

[23] Rojas, L., Vinuesa, T., Tubau, F., Truchero, C., Benz, R. and Vinas, M. (2006) Integron Presence in a Multiresistant Morganella morganii Isolate. International Journal of Antimicrobial Agents, 27, 505-512. https://doi.org/10.1016/j.ijantimicag.2006.01.006

[24] Bush, K., Jacoby, G.A. and Medeiros, A.A. (1995) A Functional Classification Scheme for $\beta$-Lactamases and Its Correlation with Molecular Structure. Antimicrobial Agents and Chemotherapy, 39, 1211-1233. https://doi.org/10.1128/AAC.39.6.1211

[25] DiPersio, J.R. and Krafczyk, T.L. (1980) In Vitro Activity of Netilmicin, Gentamicin, Tobramycin and Amikacin against Glucose Fermenting and Nonfermenting Bacteria. Chemotherapy, 26, 323-333. https://doi.org/10.1159/000237924

[26] Stock, I. and Wiedemann, B. (1998) Identification and Natural Antibiotic Susceptibility of Morganella morganii. Diagnostic Microbiology and Infectious Diseases, 30, 153-165. https://doi.org/10.1016/S0732-8893(97)00243-5

[27] Tilea, B., Szekely, E., Teches, S. and Tilea, I. (2015) Acute Community-Acquired Meningoencephalitis with Morganella morganii-A Case Report. Romanian Journal of Laboratory Medicine, 23, 333-340.

[28] Duport, C., Jobin, M. and Schmitt, P. (2016) Adaptation in Bacillus cereus. From Stress to Disease. Frontiers in Microbiology, 7, 1550.

https://doi.org/10.3389/fmicb.2016.01550

[29] Kotiranta, A., Lounatmaa, K. and Haapasalo, M. (2000) Epidemiology and Pathogenesis of Bacillus cereus Infections. Microbes and Infection, 2, 189-198. https://doi.org/10.1016/S1286-4579(00)00269-0

[30] Guinebretiere, M.H., Broussolle, V. and Nguyen-The, C. (2002) Enterotoxigenic Profiles of Food-Poisoning and Food-Borne Bacillus cereus Strains. Journal of Clinical Microbiology, 40, 3053-3056. https://doi.org/10.1128/JCM.40.8.3053-3056.2002

[31] Luna, A.V., King, D.S., Gulledge, J., Cannons, A.C., Amuso, P.T. and Cattani, J. (2007) Susceptibility of Bacillus anthracis, Bacillus cereus, Bacillus mycoides, Bacillus pseudomycoides and Bacillus thuringiensis to 24 Antimicrobials Using Sensititre Automated Microbroth Dilution and Etest Agar Gradient Diffusion Methods. Journal of Antimicrobial Chemotherapy, 60, 555-567. https://doi.org/10.1093/jac/dkm213

[32] Kervick, G.N., Flynn Jr., H.W., Alfonso, E. and Miller, D. (1990) Antibiotic Therapy for Bacillus Species Infections. American Journal of Opthalmology, 110, 683-687. https://doi.org/10.1093/jac/dkm213 